\title{
What is the nature of research conducted on regulating traditional health practitioners? A scoping review
}

\author{
Siyabonga Nzimande ${ }^{1}$, Thembelihle Zuma², Mosa Moshabela ${ }^{1}$ \\ 1 School of Nursing and Public Health, University of KwaZulu-Natal, Durban, South Africa, ${ }^{2}$ Africa Health Research Institute, Durban, South Africa \\ Keywords: traditional health practiner, regulation, traditional medicine \\ https://doi.org/10.29392/001c.28357
}

Journal of Global Health Reports

Vol. 5, 2021

\begin{abstract}
Background
Widespread use of traditional medicine (TM), the issue of their safety, combined with progressive lobbying from both practitioner groups and the public have made regulation of traditional health practitioners (THPs) an important issue. While there are questions on whether the regulation of THPs are worthwhile endeavour, literature continues to offer limited empirical evidence for clear answers. It is essential to synthesize the available literature in relation to this quest using a scoping study methodology.
\end{abstract}

\section{Methods}

This scoping review included publications from PubMed, Sabinet and Web of Science databases and included grey literature, primary research, journal reviews, published reports, as well as available policy articles. A methodological framework set out by Arksey and O’Malley was utilized.

\section{Results}

Out of 8040 searched publications, 25 met the criteria for full review. Regulation of THPs proved essential, but ways of regulating them showed many inconsistencies and challenges. The issues of recognition, integration, and colonization effects and the idea of viewing TM through a scientific lens dominated the themes arising from the 25 publications.

\section{Conclusion}

Evidence depicted that regulating THPs would be an arduous task, but the existing literature proved insufficient on the use of such regulations. However, the review calls for more studies looking at THP regulatory mechanisms, especially in developing countries, to learn best practices that embrace indigenous knowledges and promote a decolonized health system.

For the purposes of this study, regulation will refer to "the sustained and focused attempt to alter the behaviour of others according to defined standards and purposes with the intention of producing a broadly identified outcome or outcomes, which may involve mechanisms of standard-setting, information-gathering and behaviour modification". ${ }^{1}$ A traditional health practitioner (THP) is defined by the World Health Organisation (WHO) as "a person who is recognised by the community where he or she lives as someone competent to provide health care by using plant, animal and mineral substances and other methods based on social, cultural and religious practices". ${ }^{2}$ Mokgobi argues that the approach of THPs to health care is based on indigenous knowledge and belief systems. ${ }^{3}$ Generally, THPs are consulted for their explicit linkage of health with patients' social and cultural beliefs. ${ }^{4}$ This is based on African cosmology, suggesting that people see themselves as spiritual beings who are connected to ancestral spirits, which are in- visible 'members of a society who care for and carry responsibility for the actions of their descendants'.5,6 The belief in traditional health practices has been regarded as ignorant by others, including Biomedical Health Practitioners (BHPs), but continue to be well accessed by many. ${ }^{7}$

Over the years, the WHO, has presented different definitions of Traditional Medicine (TM). It previously defined $\mathrm{TM}$ as "the sum total of all the knowledge and practices, whether explicable or not, used in diagnosis, prevention and elimination of physical, mental and social imbalance and relying exclusively on practical experience and observation handed down from generation to generation, whether verbally or in writing". 6 More recently, however, the WHO defined TM as "the sum of the total knowledge, skills, and practices indigenous to different cultures, used in the maintenance of health as well as in the prevention, diagnosis, improvement or treatment of physical and mental illness". ${ }^{8}$ Aside from one of the definitions being more recently pre- 
sented, both are based on practices to diagnose and prevent illness, but the latter is more entrenched on the indigenousness of the practices, thus making it significant that TM resonate to a culture and country they originated in. This is important for the conceptualization and meaning of TM to different countries in the world, in their diversity.

An estimated $80 \%$ of the world's population recognise the use of certain traditional practices performed by THPs within primary health care. ${ }^{8,9}$ In sub-Sharan Africa one BHP treats about 40000 patients while one THP treats approximately 500 patients. ${ }^{10,11}$ In South Africa, it was estimated that 27 million people depend on traditional medicine for their primary health care needs and often utilise THPs. ${ }^{11,12}$ More so, in South Africa it was estimated that in $80 \%$ of cases, patients are reported to make use of both THP and BHP services to achieve their health care needs. ${ }^{13}$ This includes $90 \%$ of those living with HIV and AIDS who are reported to first consult THPs before BHPs, thus moving freely between THPs and BHPs. ${ }^{12,14}$

The WHO has long called for TM to be integrated into the national healthcare system ${ }^{6}$ and these calls continue to remain relevant. ${ }^{15}$ The drive from large numbers of patients who seek traditional medicines and therapies and the corresponding increase in the number of practitioners in the field has immensely contributed in assuring that discussions on TM become an important health care issue. ${ }^{16,17}$ Gqaleni et al. attest the latter by arguing that TM has sustained the health of millions of Africans over hundreds of years. ${ }^{18}$ These systems have been used for centuries, where plants were used for the treatment and prevention of various illnesses and the revolution of science has further popularised this usage, ensuring capacity within their primary healthcare. ${ }^{9}$

In its 2014 Traditional Medicine Strategy, the WHO recommends that nations take steps to regulate TM practices and practitioners. ${ }^{8}$ This could be attributed to the global growth of TM usage that attracted concerns over the safety of the products, practices and therapies utilised, as well as the concern over high prices of BHPs. ${ }^{17}$ Awodele and his colleague have also echoed this call, asking for the development of national policies and regulations to ensure safety in use and create pathways towards the integration of traditional medicines in national health systems. ${ }^{19}$ literature reveals that approximately $80 \%$ of the world's population utilises traditional healing system, this has subsequently stimulated increasing discussion on the need to regulate THPs. 8,9 This follows the promulgation of the Traditional Health Practitioners Act No.22 of 2007.9,20

Due to this global interest in the regulation of TM, particularly THPs, it is essential to synthesize the evidence using a scoping study methodology. There is limited evidence of scoping reviews focusing on policies to regulate THPs. We have come across a scoping review looking at the legislative landscape for THPs. ${ }^{21}$ This paper focuses on existing legislation among South African Development Community countries and outlines legislations, focusing specifically on definitions and classifications of THPs. ${ }^{21}$ Therefore, this paper will map literature on THP discourse and learn how the issue of regulating THPs is being handled and reported, globally. This is based on the premise that scoping reviews go far beyond their expectations based on both policy and practice and offer syntheses of findings from different types of studies. ${ }^{22}$ As such, this will allow for the identification of gaps to be potentially addressed in future research, as well as related policy implications.

\section{METHODS}

This scoping review followed a rigorous methodological framework set out by Arksey and O’Malley and was further developed by various authors utilizing a Population, Intervention, Context (PICo) search strategy tool. ${ }^{23-25}$ Due to the investigative nature of this review, and the intent to map the existing research, identify gaps and look for recurring themes within the literature, a scoping review methodology was the most appropriate methodological approach. ${ }^{26}$ This methodological approach is agued to be particularly useful for topics that are complex, have not been extensively reviewed and for which many different study designs have been used. ${ }^{23}$ Worth noting however, a scoping review does not explicitly aim to assess the quality of studies but can identify research gaps in the existing literature. Arksey and O'Malley have outlined the following five steps: Identifying the research question, identifying relevant studies, Study selection, Charting the data, Collating, summarising, and reporting of results, to be followed when conducting a scoping study. These steps were followed in conducting this study.

\section{IDENTIFYING THE RESEARCH QUESTION}

Arksey and O' Malley ${ }^{23}$ recommend starting with wide definitions for study Population, Intervention, Context (PICo) to ensure breadth of coverage in the search, and then setting parameters based on the scope and volume of references generated. Therefore, the research question for this scoping study is: What is the nature of research conducted on regulating Traditional Health Practitioners, globally.

\section{IDENTIFYING RELEVANT STUDIES}

After much deliberation and comparison of search engines the team agreed on the use of PubMed, Sabinet, and Web of Science search engines. This decision was based on the number of articles that could be retrieved, as well as the subjects and themes that could be found from such search engines, which were highly relevant to the subject matter under investigation. The relevant articles were extracted and archived in an EndNote reference manager and library. After the extraction of relevant articles into EndNote, the team went through a rigorous process of identifying relevant titles. A process of abstract review then ensued, where relevant articles based on abstract were identified and ultimately conducted a full article review, where full articles were rigorously read and those meeting the selection criteria were archived in the created subfolders. All peer reviewed and grey literature, journal reviews, published reports and policy articles were considered for this review as suggested by Arksey and O'Malley. ${ }^{23}$ To conduct the publication search, a search phrase inclusive of key words was developed. This was made up of keywords from the title as well as synonyms of keywords from the title and key- 
words of seminal papers related to the study, as depicted in table 1. A reasonable number of articles was considered, to ensure that relevant articles were not excluded, while ensuring that the number of articles are not too many to be covered, considering the popularity of the topic in question. For this topic, search phrases that brought up less than hundred articles were not enough and search words that brought up hundreds of thousands of articles for example, were considered too high. After several preliminary attempts in combining different keywords using the chosen databases, the following search phrase was used for the study ("traditional medicine" OR "herbal medicine") AND (African OR Indian OR Korean OR Vietnamese OR Chinese OR Indonesian) AND "traditional health practitioners" AND (regulation), as a Boolean search query. Having more than one word in inverted commas meant they must appear together as in the quotation marks to be picked up in the search, the use of 'OR' here gave room to add synonyms or alternative words or phrases to the search. Using 'AND' meant the articles to be picked up in the search must have the first bracketed phrases plus the next. The terms of countries used here are synonyms identified under traditional medicine, such as African traditional medicine, Indian traditional medicine, Korean traditional medicine, etcetera and were found in seminal papers read in solidify our search phrase. Cooke and his colleagues ${ }^{24}$ indicate that keywords, relying on the clarity in the title, assist with effective retrieval terms but also place an onus on the indexer's interpretation of the full article. ${ }^{24}$ In order to prevent bias and provide a true representation of available research one had to focus on the comprehensiveness of the search process, as articulated by various authors. ${ }^{27}$ The search phrases in this study ensured that a high level of comprehensiveness was attained.

\section{STUDY SELECTION CRITERIA}

This study took place from September 2018 to January 2019 and notifications for new studies meeting the search phrase were set with the listed search engines, to update the study with latest publications. Due to the complexity of terms used in different countries to refer to TM and their regulatory mechanisms, and the hope to cover as many publications as possible, no period was set for the search criteria.

Arksey and O'Malley ${ }^{23}$ recommend that an inclusion and exclusion criteria of studies be utilised when one has undergone a thorough process with the literature. Moreover, Armstrong et al. ${ }^{28}$ suggest identifying a series of inclusion and exclusion criteria to allow for the removal of irrelevant papers. This scoping study utilised the following inclusion/ exclusion criteria:

- literature published in peer reviewed journals included in PubMed, Sabinet, and Web of Science databases. This included peer reviewed and grey literature, primary research, journal reviews, published reports, as well as policy articles.

- All study designs (quantitative, qualitative, and mixed methods) were included for review. Only literature presented in English was considered, thereby excluding all articles published in other languages.

- Reference lists were employed to source literature otherwise not picked up using the key words identified. All publications including traditional medicine, traditional health practitioners and regulation were included, as they also informed the Boolean search query.

- Due to this study being a global review, countries names were not considered for inclusion or exclusion nor were years of publication.

\section{CHARTING THE DATA}

For the purpose of this scoping review, data synthesis and interpretation adopted a narrative or descriptive approach in place of a more systematic data extraction or analytic method, as suggested by Arksey and O'Malley. ${ }^{23}$ As recommended by Armstrong et al., ${ }^{28}$ a spreadsheet was created to chart relevant data, based on the focus of the scoping question in order to source common themes, gaps and to review authors identified from the different articles. Charted data were then entered into a spreadsheet to ensure that the data captured were comparable between included articles. The data collection categories included: authors, year of publication, study location, interest type, study population, aims of the publication, overview of methods, results, and recommendations.

\section{COLLATING, SUMMARISING, AND REPORTING OF RESULTS}

An argument levelled by Arksey and O’Malley ${ }^{23}$ is that emphasis should not be placed on the "weight of evidence" nor on evaluating the quality of evidence, but a thematic framework to guide the narrative account of existing literature is recommended. To enable a comprehensive collation and summary of results, Armstrong and his colleagues ${ }^{28}$ stress the importance of investing much time and energy in the charting of studies arguing this on the premise that "the strength of a scoping review lies not in the assessing of quality included in studies, but in providing an overview of existing literature". ${ }^{28}$ Having levelled this, this study took full advantage of utilising a thematic analysis, synthesized and collated various themes that emerged from the data onto an extraction sheet. This extraction sheet informed all study design results, and this became a platform for synthesizing various findings and arguments on the regulation of THPs. After this synthesis and collation of data, summaries were generated and combined for reporting purposes. This assisted in applying meaning to the results and increased consistency in reporting of results, as recommended by advocators of scoping reviews. ${ }^{29}$ Therefore, in this scoping study, we have managed to map available literature and highlighted gaps identified using the abovementioned Boolean search query and key words.

\section{RESULTS}

The initial search produced 8040 articles (Table 2). After the removal of non-English articles, unrelated topics, and duplicates, 441 articles remained. This was then further refined to 222 after reading through the abstracts. There 
Table 1: Key words sourced

\begin{tabular}{|c|c|c|}
\hline Population & Intervention & Context \\
\hline \multicolumn{3}{|l|}{ Primary key words } \\
\hline African traditional medicine & Regulation & Global \\
\hline African traditional healing & Adjustment & World \\
\hline Indian traditional medicine & Arrangement & \\
\hline Korean traditional medicine & Control & \\
\hline Traditional Vietnamese medicine & Management & \\
\hline Traditional Chinese medicine & Governance & \\
\hline Indonesian traditional medicine & Supervision & \\
\hline \multicolumn{3}{|l|}{ Traditional medicine } \\
\hline \multicolumn{3}{|l|}{ Herbal medicine } \\
\hline \multicolumn{3}{|l|}{ Herbal healing } \\
\hline \multicolumn{3}{|l|}{ Botanical medicine } \\
\hline \multicolumn{3}{|l|}{ Hanbang medicine } \\
\hline \multicolumn{3}{|l|}{ Traditional healing } \\
\hline \multicolumn{3}{|l|}{ Complementary/alternative medicine } \\
\hline \multicolumn{3}{|l|}{ Traditional health practitioner } \\
\hline \multicolumn{3}{|l|}{ Secondary key words } \\
\hline Ayurveda system & Administration & \\
\hline Folk medicine & Standardisation & \\
\hline Natural medicine & Reconciliation & \\
\hline Holistic medicine & Reorganisation & \\
\hline Unconventional medicine & Systemisation & \\
\hline \multicolumn{3}{|l|}{ Acupuncture } \\
\hline \multicolumn{3}{|l|}{ Ayurveda } \\
\hline \multicolumn{3}{|l|}{ Homeopathy } \\
\hline Naturopathy & & \\
\hline
\end{tabular}

were 25 articles that remained for review, after thoroughly reading full articles to establish relevance. 17 papers were based on reviews, 3 were editorials and the rest were opinion, qualitative, quantitative, document analyses and 1 randomised control trial. All the included publications were reviewed and synthesized, then summarized in a matrix form, in terms of the aims of the review. Figure 1 illustrates the article selection process and unpacks the different criteria used to reach the final articles for review.

The key data from the 25 publications covered in this scoping review are summarized in Tables 2 . Most of the review articles were published between 2000 and 2018 with only two (1994 and 1998) published during the 1990s. Publications were based on studies conducted in ten countries. Most papers were derived from South Africa (13 articles) and the United Kingdom ( 3 articles). Most of the studies were conducted in developing countries (15 articles). Despite the history in TM in China, few articles were found in this region, potentially attributed to the language and lack of freely accessible publications. Although this is a limitation, the present review summarizes the available data from around the globe and highlighted studies conducted on the regulation of THPs.
Emerging themes from the current scoping review included effects of colonialism on TM, recognition of THPs, scientific mindset to TM and integration of TM and biomedical health systems (BHS).

\section{EFFECTS OF COLONIALISM ON TRADITIONAL MEDICINE SYSTEMS}

Authors propose that TM will require ground-breaking regulatory approaches to address safety and quality of care and argue that this will need to ensure that it redresses historical inequalities, thus ensuring that key public populations' interests are catered for. ${ }^{30}$ This will also cater for the protection of diverse indigenous knowledge, and delivery of care to underserved populations, especially due to the concern that the history of medical pluralism with its associated colonialism, globalization or internationalism is marked by evil intentions. ${ }^{30}$ This comes on the back-drop of the realization that international organizations, such as the WHO, suggest the success of the primary healthcare delivery in developing countries depends on TM. ${ }^{31}$ It would therefore appear that some international consensus with respect to education and practice standards would enhance 
Table 2. Total number of articles retrieved

\begin{tabular}{|l|l|}
\hline \multicolumn{2}{|c|}{ Produced articles from the Boolean search phrase } \\
\hline Search engine & Number of articles retrieved \\
\hline PubMed & 3457 \\
\hline SABINET & 4194 \\
\hline Web of Science & 389 \\
\hline
\end{tabular}
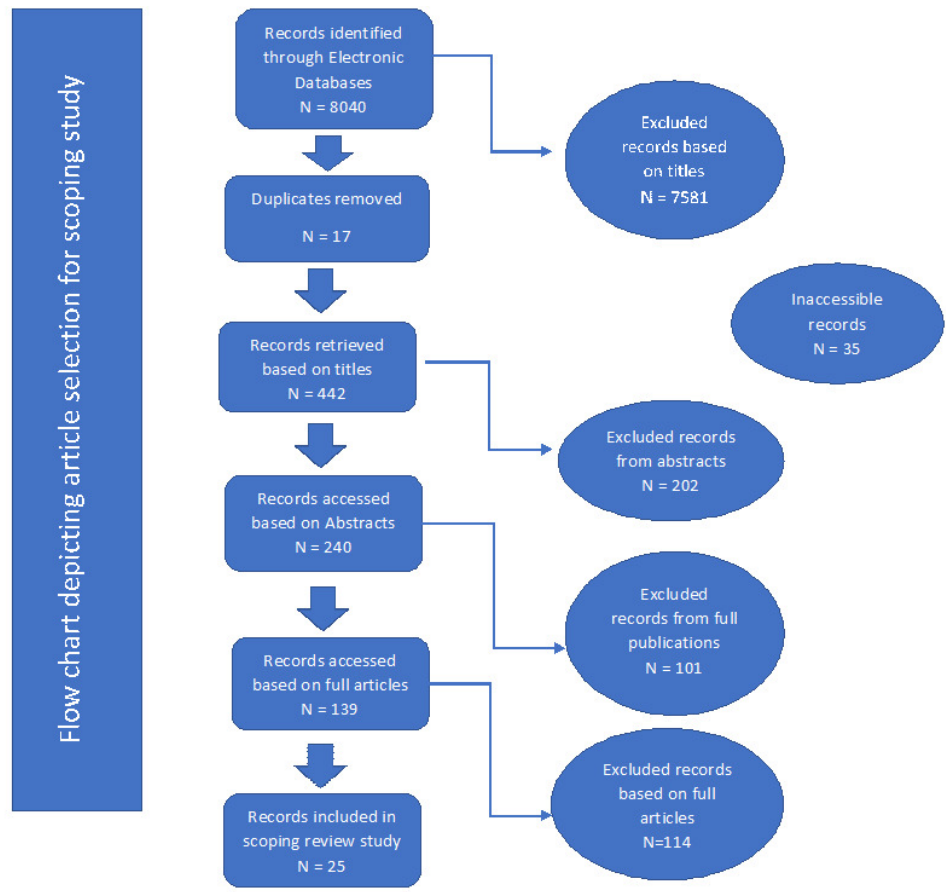

Figure 1. Flow chart of article selection for the scoping review

public safety and facilitate collaborative research on the safety and efficacy of complementary/alternative medicine (CAM) practices. ${ }^{16}$

This is important to regulators of THPs because already European institutions are starting to influence the development of TM. Therefore, to ensure success in proper regulation, the international community will have to share experiences with respect to regulating the THPs. ${ }^{16}$ However, harmonisation of training and regulation of practitioners continues to a challenge for the future. More so, it is believed that the interests of patients will best be served by a process of education, investigation, and regulation involving various stakeholders such as the public, doctors and health professionals, other practitioners, and national authorities. ${ }^{32}$ Even if all stakeholders stand to gain by the promotion of the institutionalisation of THPs, it is unclear how this is to be done. ${ }^{33}$ However, there is an argument that the South African health care delivery system needs to shift from a system dominated by Western-based health practices to a network of shared responsibilities; an integrated health care system in which THPs also serve in the provision of health care. ${ }^{34}$

\section{RECOGNITION OF TRADITIONAL HEALTH PRACTITIONERS}

Although THPs have been consulted by a large proportion of the South African population for many years, they enjoyed no official recognition until the government was obliged to publish the Traditional Health Practitioners Bill (B20/2007). ${ }^{35}$ The process was certainly not a simple one, as much consultation and delays were involved, including the Act being considered invalid, due to insufficient of participation during the consideration of the Act. ${ }^{36}$ However, this Act has got to be a breakthrough in attempts to recognise THPs. After all, THPs are viewed as an integral part of communities and are viewed by community members as important providers of health care. ${ }^{37}$ The promulgation of the THP Act of 2007 gave way to the THP proposed regulation, which has however been argued to lack of substantive detail and leaves a lot of room for interpretation and speculation. ${ }^{36}$

Authors believe that successful implementation of regulating THPs will assist in ensuring that THPs are recognised, but continue to view the regulation process as sporadic, insufficient and controversial. ${ }^{38}$ They however remain opti- 
mistic that THP recognition will ensure that THPs are on an equal footing with other healthcare practitioners in South Africa and therefore oblige employers to honour sick notes issued by THPs, although there are still concerns with the delay in establishing an Interim THP Council, but this has not stopped the mobilisation of an estimated 200000 THPs in South Africa who belong to over 100 separate organisations. ${ }^{38,39}$ Finalisation of THP regulations will also stand a chance to overturn the ruling that sees THPs being barred from using titles such as 'acupuncturist' because their recognition will prove that they meet certain standards, which are yet to be clarified. ${ }^{39}$ With statutory recognition will come the issuing of provider practice numbers to practitioners, the formalisation of tariff structures and increased visibility for traditional medicine. ${ }^{40}$ Attention is urgently needed to ensure that barriers to inclusion of THPs are removed and thus the excuses offered by trustees of medical schemes are invalidated, so government could prioritise THPs inclusion in medical aid schemes and medical scheme trustees advocacy will be essential. ${ }^{41}$

Unfortunately, it is not yet certain how regulation would work alongside practitioners' current registration with recognised organisations such as the Nursing and Midwifery Council or General Medical Council. What is useful though, is that regulators need to ensure that part of the function of regulating THPs should be to recognize the existence of these 'unconventional' healing methods and to encourage and mould them in a socially desirable direction. ${ }^{42}$ This considers the idea that regulating of THPs by government could hamper the access of traditional communities to THPs and the Act might become mere paper law. ${ }^{35}$ Others argue that establishing a council for THPs may not be sensible and could face insurmountable problems but agree that regulations will assist in recognition of THPs and would address some of South Africa's major health challenges. ${ }^{34}$ Moreover, greater recognition for and regulation of THPs in South Africa's legal and national health systems especially when considering the potential positive impact of traditional therapeutic properties in the context of HIV and AIDS, comes highly recommended.

\section{SCIENTIFIC MINDSET TO TRADITIONAL MEDICINE SYSTEMS}

It is argued that a systematic and scientific 'mindset' is required to develop THPs parallel to BHPs, and that proposed regulations will essentially create a more restrictive environment for THPs and traditional African medicine than the pre-1994 conditions. ${ }^{43}$ More so, the source of knowledge and basis of science of the two disciplines, THPs and BHPs is believed to be so different that they are incompatible, but the future seems to suggest that THPs and African Traditional Medicine will be highly regulated and subject to similar scientific processes as BHPs. ${ }^{43}$ Epistemic and evidentiary tensions, as well as the policy complexities surrounding the intersection of cultural and clinical considerations, present additional challenges to regulators. ${ }^{30}$

Another concern is that If traditional medicines are to be prescribed, marketed and sold as part of a healthcare system recognised under SA law, they must meet the same stringent standards. ${ }^{36}$ If this is to be the case, then a lot has to be considered because humans have an infinite capacity for beliefs, which would pose a challenge to regulate, especially THPs, whose remedies are provided by belief systems. ${ }^{34}$ On the hand, if THPs are left to go through a number of years of education and training within their ancient belief-system, there is a possibility of generating practitioners that could cause harm, but forcing them to practice according to evidence-based medicine principles is argued might regulate THPs into oblivion. ${ }^{44}$ Significant efforts have been made in validating the quality, effectiveness, and safety of THP interventions evidenced by a growing number of published trials and systematic reviews, but the results of these studies are argued to be inconclusive due to the lack of quality and quantity of the trials to answer specific and answerable clinical questions. 45

Moreover, the need to maintain communication between patients, doctors and THPs remains essential and needs to be part of the medical curriculum, and doctors do not have time to search for the appropriate information when advice is sought ${ }^{46}$ and the lack of patient disclosure further compounds the problem. ${ }^{47}$ As much as it has been deemed difficult to conduct randomised control trials using traditional medicines, their use continues to be widespread, although the true extent of drug interactions is not exactly known. ${ }^{47}$ This lack of public health research is a global phenomenon, particularly in countries where TM is a form of primary health care, such as in China, although there has been promising evidence of some traditional medicines for the treatment of priority diseases such as malaria and HIV and AIDS. ${ }^{45}$

However, there remains little empirical evidence to support the use of THP regulations and the poor disciplinary record of comparable regulatory bodies in developed countries is argued to pose difficulties in enforcing laws in developing countries. ${ }^{42}$ This does not mean that regulation cannot serve a useful purpose because of the idea that regulation is not only about disciplining the practitioners who do not toe the line but could involve 'correcting market imperfections, shaping norms, applying self-imposed standards, and other informal constraints'. ${ }^{42}$

\section{INTEGRATION OF TRADITIONAL HEALTH PRACTITIONERS AND BIOMEDICAL HEALTH PRACTITIONERS}

Authors argue that the integration of TM into public and private facilities and the reimbursement by medical schemes is far behind with respect to legislative developments. ${ }^{41}$ Integrating TM into South Africa's health-care system is seen as a complex undertaking but more concerning is the believe that the government's response fails to reassure that the magnitude and significance of the challenge is appreciated. ${ }^{48}$ Others recommend that a development of a mixed healthcare system would be a balanced undertaking in a zone that combines non-discrimination between medical traditions with neither full fusion nor total separation, but rather strong cross-sectional links between distinct traditions. ${ }^{49}$ More so, Psychiatric services and institutions are recommended to be the first logical contact for optimal integration if South Africa were to investigate the integration of THPs into primary health care. ${ }^{50}$ Already some BHPs 
have studied TM and utilize some of its therapies and some doctors have started experimentally practising with traditional medicines. ${ }^{51}$

Despite these potential drawbacks many people believe they derive real benefit from THPs, and this is supported by evidence that has come from clinical trials of Chinese Traditional Medicines used for eczema. ${ }^{46}$ Similarly, South Africa has made great strides in the integration of THPs into the national health system which is mainly based on BHPs. ${ }^{52}$ However, more interventions are needed from government, although state policies have evolved in this context Therefore, even if all stakeholders stand to gain by the promotion of the institutionalisation of THPs, it is unclear how this is to be done, but implementing a model for integration that will be developed around 'effective communication, mutual respect and trust, reciprocal education and training, two-way referral, scientific testing of traditional medicines, would be ideal. 33

Increased use of THPs in the community, with risks arising from both the specific practices as well as consumers negotiating a parallel primary health care system continue to be witnessed and while statutory regulation seems to win popular votes. It is argued that a minimalist regulatory response needs to be accompanied by other measures to educate the public in order to understand the interaction between TM and mainstream health care. ${ }^{53}$ This therefore supports the integration of THPs into the official health care systems but highlights that more interventions will be needed to allow proper implementation involving changes at grassroots level, which are believed to be the real challenge. ${ }^{37}$ More so, acceptance and respect for their respective fields of truth has enabled health professionals to integrate successfully with THPs. ${ }^{34}$ Similarly, some authors argue that a model for integrating THPs into the SA national healthcare delivery system was developed around 'effective communication, mutual respect and trust, reciprocal education and training, two-way referral, scientific testing of traditional medicines. ${ }^{33}$

\section{DISCUSSION}

The results of this scoping review showed that THPs are an integral part of communities and viewed by the public as important providers of healthcare, but regulating them has proved as an arduous task, meddled with challenges and inconsistencies. These findings have been witnessed throughout the globe, regardless that these THPs have been instrumental in sustaining the health of millions over hundreds of years. ${ }^{41}$ Worth noting, is the increased interest and publications in South Africa post 1994, when TM were escalated to the national health agenda by the African National Congress Health Plan of 1994. This was followed by the Homeopaths and Allied Health Professions Act of 1996, endorsed by a white paper for the Transformation of Health Systems of 1997 and these efforts paved way for the 2003 Traditional Health Practitioners Bill, which was later amended in 2007 and finally gave way to a long anticipated Traditional Health Practitioners' Regulation in 2015.35,35,35-37,47 Other countries around the globe had already made great inroads to the recognition of TM, but the WHO played a significant role in placing the regulation of TM on the agenda through its 2014 Traditional Medicine Strategy. ${ }^{30}$ However, their regulatory environment has presented unique challenges and opportunities for the regulation on THPs, referred to as CAM practitioners. Where they struggled with the unification of regulatory structures, often compounded by the lack of cohesion among CAM practitioner groups, yet still also receive a high public demand for their health care services. ${ }^{16}$ Moreover, even training duration of different THPs bodies appear to be problematic to regulators, but more concerning is the idea of regulators attempting to view and regulate THPs using a modern scientific lens. This is argued to have negative consequences, where some publications protest that it could regulate THPs into oblivion. ${ }^{44}$

Regulation of THPs does not appear as a straight-forward endeavour, especially because of published colonial intrusions, where literature cites that regulatory approaches will need to ensure that it redresses historical inequalities in African countries in order to cater for the interests of key public populations. ${ }^{30}$ Now this is a serious concern because international organizations are aware that the success of primary healthcare delivery in developing countries depends very much on TM and even argue that successful and proper regulation will require that international communities share experiences with respect to regulating of THPs. ${ }^{31}$ However, there remains little empirical evidence to support the use of THP regulations and the poor disciplinary record of comparable regulatory bodies in developed countries is argued to pose difficulties in enforcing laws in developing countries. ${ }^{42}$ This lack of empirical evidence is argued to be global phenomenon, particularly in countries where TM is a form of primary health care, such as in China. Although there has been promising evidence of some traditional medicines for the treatment of priority diseases such as malaria and HIV and AIDS, but the results of these studies were argued to be inconclusive due to the lack of quality and quantity of the trials to answer specific and answerable clinical questions. ${ }^{45}$

Part of the findings of this scoping review offer different ways that THP regulations should be viewed from. This is evidenced in Powlowski's publication, where he argues that regulation can serve a useful purpose through correcting market imperfections, shaping norms, applying self-imposed standards, and not be viewed as just disciplining practitioners who do not toe the line. ${ }^{42}$ This is contrary to other publications which argued that enforcing penalties and punishing THPs by stripping them of their titles because of not being able to prove they can meet certain standards. ${ }^{39}$ This is therefore indicative of the different modalities and ways through which regulators perceive THP regulations. Therefore, integrating TM into South Africa's health-care system, for example, is seen as a complex undertaking but more concerning is the believe that the government's response fails to reassure that the magnitude and significance of the challenge is appreciated. ${ }^{48}$

An interesting observation and question asked by Van Niekerk is that most traditional practices are based on belief and humans are believed to have an infinite capacity for beliefs, so can beliefs be regulated and if so, how. ${ }^{34}$ This observation and question are evidence that regulating THPs is and will remain a difficult task, thus calling for empirical evidence that will offer ways on how best could THPs be 
regulated. Unfortunately, this scoping study has provided evidence on the dire shortage of THP regulatory mechanisms from across the globe, but worth mentioning is that there is some evidence on the regulation of medicines and therapies used by THPs, but regulation of THPs remains sporadic and insufficient.

\section{RECOMMENDATIONS}

Government departments charged with the responsibility of regulating THPs will have to seriously consider the interests of THPs as custodians of this practice and ensure that they are well protected if they really believe in the strength of TM. This review highly recommends the involvement of THP organisations, to understand their role in the regulatory process. Learning from international communities is important. However, developing countries, especially those who suffered under colonial subordination, will have to shift from western dominated health systems and begin to work on systems that will be suitable for their diverse indigenous knowledges, thus also redressing historical inequalities. More relevant studies will also be required to ensure best practices and to allow for replication. This scoping study also cemented a pathway into a mixed healthcare system, suggesting a missed opportunities from the regulatory bodies. Therefore, suggesting parallel medical traditions with no discrimination between the two medical traditions.

\section{LIMITATIONS}

This review considered articles only published in English and that were freely accessible in the highlighted search engines. Therefore, various articles which could have enhanced the rigour of this review might have been missed. The articles' selection process was initially carried-out by the author, but later verified by the team, which could have introduced bias in the process. This publication does not offer an assessment of quality in the articles retrieved but provide an overview of existing literature. Despite these limitations, a thorough review was conducted of the included articles.

\section{CONCLUSIONS}

This scoping review study offers an overview of literature on the regulation of THPs around the globe. South Africa seems to have more publications on the searched topic, but it is important to note that no empirical evidence on the regulation of THPs is offered by their listed publications. However, studies on the regulation of traditional medicines seems rife. Another point worth noting is the lack of focus on THP regulations from developed countries. This indicates that THPs have not been a central focus to regulatory bodies around the globe, but South Africa, with its various categories of THPs seems to show more interest, especially after 1994. The review has also highlighted challenges and advantages of regulating THPs but could not source ways in which other countries have managed to regulate their THPs. This should draw more attention on the regulatory mechanisms offered by the various countries and seek to find how best THPs could be regulated. At this stage, literature offers too little empirical evidence to support the use of THP regulations.

Regulation of THPs will not be an easy endeavour but ensuring some form of regulation will go a long way in protecting the consumers of TM from potential harm. The review highlights that recognition and encouragement that would mould THPs in a socially desirable direction should form part of the function of laws regulating, as suggested by Powlowski. ${ }^{42}$ Having fair and consultative regulations will certainly allow THPs to be on par with other healthcare practitioners. Failure to achieve this will likely lead to a more restrictive environment for THPs. Developing countries will need strong and informed leadership that will not be based of political manipulation, so as not to cause harm to an already limping health-care system. 
Table 3. Summary on the regulation of traditional health practitioners scoping review

\begin{tabular}{|c|c|c|c|c|c|c|c|c|}
\hline Number & Authors & $\begin{array}{l}\text { Year of } \\
\text { publication }\end{array}$ & $\begin{array}{l}\text { Study } \\
\text { location }\end{array}$ & Interest type & $\begin{array}{l}\text { Study } \\
\text { population }\end{array}$ & Aims of publication & $\begin{array}{l}\text { Overview of } \\
\text { methods }\end{array}$ & Results \\
\hline 1 & 31 & 2016 & Ghana & $\begin{array}{l}\text { Advocacy, } \\
\text { recognition and } \\
\text { demarginalization } \\
\text { of Traditional } \\
\text { Medicine }\end{array}$ & $\begin{array}{l}\text { Traditional } \\
\text { Medicine } \\
\text { Practitioners }\end{array}$ & $\begin{array}{l}\text { Elucidation advocacy work toward } \\
\text { medical pluralism in Ghana. }\end{array}$ & Review & $\begin{array}{l}\text { There is a growing concern that colonialism, globalization, or internationalism } \\
\text { has marked medical pluralism with malicious intentions. Whilst various } \\
\text { governments in Africa and internationally have realized that success of } \\
\text { primary healthcare delivery in developing counties in dependent on } \\
\text { Traditional Medicine. }\end{array}$ \\
\hline 2 & 38 & 2012 & $\begin{array}{l}\text { South } \\
\text { Africa }\end{array}$ & $\begin{array}{l}\text { Current } \\
\text { legislation, } \\
\text { challenges and } \\
\text { the way forward }\end{array}$ & $\begin{array}{l}\text { Traditional } \\
\text { Healers }\end{array}$ & $\begin{array}{l}\text { The registration and recognition of } \\
\text { THPs in South Africa. }\end{array}$ & $\begin{array}{l}\text { Forum/ } \\
\text { Review }\end{array}$ & $\begin{array}{l}\text { Regulation of Traditional Health Practitioners and medicines has been } \\
\text { sporadic, insufficient, and controversial and once finalised, it will oblige } \\
\text { employers to honour sick notes issued by THPs. The lack of efficiency in } \\
\text { establishing the Interim THP Council has not stopped THP organizations from } \\
\text { mobilizing. }\end{array}$ \\
\hline 3 & 43 & 2017 & $\begin{array}{l}\text { South } \\
\text { Africa }\end{array}$ & $\begin{array}{l}\text { Regulation of } \\
\text { Allopathic and } \\
\text { traditional health } \\
\text { practitioners }\end{array}$ & $\begin{array}{l}\text { Allopathic and } \\
\text { traditional } \\
\text { health } \\
\text { practitioners }\end{array}$ & $\begin{array}{l}\text { Opinion paper is a response to } \\
\text { Nemutandani et al.'s paper, to } \\
\text { negate its claims about the } \\
\text { Witchcraft Suppression Act of } \\
1957 \text {, to provide some clarity on } \\
\text { the Traditional Health } \\
\text { Practitioners Act No. } 22 \text { of } 2007 \\
\text { and related policies and } \\
\text { regulations. }\end{array}$ & $\begin{array}{l}\text { Opinion/ } \\
\text { review }\end{array}$ & $\begin{array}{l}\text { THPs and BHPs are founded on two different disciplines and stem from } \\
\text { separate sources of knowledge which are incompatible. However, the future } \\
\text { suggests that THPs and African Traditional Medicines will be highly regulated } \\
\text { and subject to similar scientific processes and BHPs. }\end{array}$ \\
\hline 4 & 39 & 2009 & $\begin{array}{l}\text { United } \\
\text { Kingdom }\end{array}$ & $\begin{array}{l}\text { Regulation of } \\
\text { Alternative } \\
\text { therapists }\end{array}$ & $\begin{array}{l}\text { Alternative } \\
\text { therapy }\end{array}$ & $\begin{array}{l}\text { The regulation of practitioners } \\
\text { who use alternative medicine } \\
\text { techniques. }\end{array}$ & Review & $\begin{array}{l}\text { THPs run the risk of being barred from using titles such as 'acupuncturist' } \\
\text { unless they can prove they meet certain standards. Unfortunately, these } \\
\text { standards are yet to be clarified. }\end{array}$ \\
\hline 5 & 50 & 2014 & $\begin{array}{l}\text { South } \\
\text { Africa }\end{array}$ & $\begin{array}{l}\text { Opinions of } \\
\text { healthcare } \\
\text { professionals } \\
\text { about traditional } \\
\text { healing and the } \\
\text { regulation of } \\
\text { their practices }\end{array}$ & $\begin{array}{l}\text { Traditional } \\
\text { Healing }\end{array}$ & $\begin{array}{l}\text { The assessment of Health care } \\
\text { practitioners' opinions about } \\
\text { traditional healing and regulating } \\
\text { of traditional healers }\end{array}$ & Quantitative & $\begin{array}{l}\text { Moderate opinions about traditional healing in South Africa have been } \\
\text { expressed by BHPs and they argue that If South Africa considers investigating } \\
\text { in the integration of traditional healers into primary health care, the discipline } \\
\text { of psychiatry would be the first logical contact for optimal integration. }\end{array}$ \\
\hline 6 & 42 & 2006 & $\begin{array}{l}\text { North } \\
\text { Carolina }\end{array}$ & $\begin{array}{l}\text { The Regulation of } \\
\text { Traditional } \\
\text { Practitioners }\end{array}$ & $\begin{array}{l}\text { Traditional } \\
\text { Practitioners }\end{array}$ & $\begin{array}{l}\text { To consider the wisdom of } \\
\text { regulating traditional practitioners } \\
\text { in developing countries that have } \\
\text { yet to regulate the profession. }\end{array}$ & Review & $\begin{array}{l}\text { There is insufficient empirical evidence to support the use of THP regulations } \\
\text { and the poor disciplinary record of comparable regulatory bodies in } \\
\text { developed countries makes it difficult to enforce disciplinary measures on } \\
\text { THPs. However, there are arguments that regulations of THPs should rather } \\
\text { be viewed as correcting market imperfections, shaping norms, applying self- } \\
\text { imposed standards, and other informal constraints rather than just being } \\
\text { viewed as disciplining THPs who do not toed the line. }\end{array}$ \\
\hline 7 & 35 & 2007 & $\begin{array}{l}\text { South } \\
\text { Africa }\end{array}$ & $\begin{array}{l}\text { New Legislative } \\
\text { Framework for } \\
\text { Traditional } \\
\text { Healers }\end{array}$ & $\begin{array}{l}\text { Traditional } \\
\text { Healers }\end{array}$ & $\begin{array}{l}\text { Review on a New Legislative } \\
\text { Framework for Traditional Healers } \\
\text { in South Africa. }\end{array}$ & Review & $\begin{array}{l}\text { THPs have been consulted by numerous people for many years but did not } \\
\text { enjoy any official recognition until the Traditional Health Practitioners Bill } \\
\text { (B20/2007). }\end{array}$ \\
\hline 8 & 36 & 2016 & $\begin{array}{l}\text { South } \\
\text { Africa }\end{array}$ & $\begin{array}{l}\text { New proposed } \\
\text { regulations for } \\
\text { South African }\end{array}$ & $\begin{array}{l}\text { regulations for } \\
\text { South African } \\
\text { traditional }\end{array}$ & $\begin{array}{l}\text { Unpacking the new proposed } \\
\text { regulations for South African } \\
\text { traditional health practitioners }\end{array}$ & Editorial & $\begin{array}{l}\text { An unfortunate phenomenon about the proposed THP regulation of South } \\
\text { Africa is that it is believed to lack substantive detail and to leave a lot of room } \\
\text { for interpretation and speculation. }\end{array}$ \\
\hline
\end{tabular}




\begin{tabular}{|c|c|c|c|c|c|c|c|c|}
\hline Number & Authors & $\begin{array}{l}\text { Year of } \\
\text { publication }\end{array}$ & $\begin{array}{l}\text { Study } \\
\text { location }\end{array}$ & Interest type & $\begin{array}{l}\text { Study } \\
\text { population }\end{array}$ & Aims of publication & $\begin{array}{l}\text { Overview of } \\
\text { methods }\end{array}$ & Results \\
\hline & & & & $\begin{array}{l}\text { traditional health } \\
\text { practitioners }\end{array}$ & $\begin{array}{l}\text { health } \\
\text { practitioners }\end{array}$ & & & \\
\hline 9 & 37 & 2006 & $\begin{array}{l}\text { South } \\
\text { Africa }\end{array}$ & $\begin{array}{l}\text { The incorporation } \\
\text { of African } \\
\text { traditional health } \\
\text { practitioners into } \\
\text { the South African } \\
\text { health care } \\
\text { system }\end{array}$ & $\begin{array}{l}\text { African } \\
\text { Traditional } \\
\text { health } \\
\text { practitioners }\end{array}$ & $\begin{array}{l}\text { This article offers a critical } \\
\text { Reflection on national and } \\
\text { international policies of African } \\
\text { traditional medicine }\end{array}$ & Review & $\begin{array}{l}\text { THPs are viewed as an integral part of communities and viewed by community } \\
\text { members as important providers of health care and their integration into } \\
\text { official health care systems is supported and encouraged by the international } \\
\text { community. This therefore makes the THP Act of } 2007 \text { to be viewed as a } \\
\text { breakthrough in attempts to legitimise and professionalise THPs. }\end{array}$ \\
\hline 10 & 34 & 2012 & $\begin{array}{l}\text { South } \\
\text { Africa }\end{array}$ & $\begin{array}{l}\text { Traditional } \\
\text { Healers } \\
\text { Formalised }\end{array}$ & $\begin{array}{l}\text { Traditional } \\
\text { Healers }\end{array}$ & $\begin{array}{l}\text { An editorial on the formalisation } \\
\text { of traditional healers and a look at } \\
\text { regulating traditional healers }\end{array}$ & Editorial & $\begin{array}{l}\text { The greatest challenge is on trying to regulate beliefs and this is based on the } \\
\text { notion that humans have an infinite capacity for beliefs. These belief systems } \\
\text { have formed part of remedies provided by THPs and have been argued not to } \\
\text { meet the requirements of current medical registration system. }\end{array}$ \\
\hline 11 & 48 & 2006 & $\begin{array}{l}\text { South } \\
\text { Africa }\end{array}$ & $\begin{array}{l}\text { The regulation of } \\
\text { Traditional } \\
\text { Medicine }\end{array}$ & $\begin{array}{l}\text { Traditional } \\
\text { Medicine }\end{array}$ & $\begin{array}{l}\text { Assessing the feasibility of } \\
\text { integrating Traditional Medicine in } \\
\text { South Africa's health system }\end{array}$ & Review & $\begin{array}{l}\text { There is no lack of confidence in the South African government's response to } \\
\text { the integration of traditional medicine into the countries health-care system } \\
\text { because of their failure to reassure the public that they fully appreciate the } \\
\text { magnitude and challenge of the issue. }\end{array}$ \\
\hline 12 & 16 & 2002 & Canada & $\begin{array}{l}\text { Regulation of } \\
\text { complementary/ } \\
\text { alternative } \\
\text { medicine }\end{array}$ & $\begin{array}{l}\text { Complementary/ } \\
\text { alternative } \\
\text { Medicine }\end{array}$ & $\begin{array}{l}\text { Regulating the practice of CAM in } \\
\text { Canada }\end{array}$ & $\begin{array}{l}\text { Policy } \\
\text { review and } \\
\text { Qualitative } \\
\text { Data } \\
\text { analyses }\end{array}$ & $\begin{array}{l}\text { It is evident that regulation various widely across countries and this era of } \\
\text { regulation reform have given various countries to review their traditional } \\
\text { medicine regulatory status on many health care professions and providers, } \\
\text { especially across Canada. }\end{array}$ \\
\hline 13 & 40 & 2001 & $\begin{array}{l}\text { South } \\
\text { Africa }\end{array}$ & $\begin{array}{l}\text { The legal } \\
\text { framework for } \\
\text { the practice of } \\
\text { complementary } \\
\text { medicine in South } \\
\text { Africa. }\end{array}$ & $\begin{array}{l}\text { Complementary } \\
\text { Medicines }\end{array}$ & $\begin{array}{l}\text { Consideration of Regulatory } \\
\text { developments on complementary } \\
\text { medicine. }\end{array}$ & Review & $\begin{array}{l}\text { There is hope that statutory recognition of THPs will bring about the issuing } \\
\text { of provider practice numbers, formalise their tariff structures and increase } \\
\text { their visibility and this is believed will empower consumers to increasingly } \\
\text { question health plans that exclude THPs recognised modalities. }\end{array}$ \\
\hline 14 & 51 & 2000 & Korea & $\begin{array}{l}\text { The Politics of } \\
\text { Herbal Medicine } \\
\text { in Korea }\end{array}$ & Herbal Medicine & $\begin{array}{l}\text { The agitation by Koreans for } \\
\text { recognition in their state- } \\
\text { sponsored health system for the } \\
\text { state to support Hanbang } \\
\text { Medicine. }\end{array}$ & Review & $\begin{array}{l}\text { As much as there remains an outcry for government interventions on } \\
\text { traditional medicine use, it is gratifying to learn that some BHPs study } \\
\text { Hanbang medicine and have begun experimenting with Hanuisas, which are } \\
\text { traditional medicine remedies that have not been in the domain of their } \\
\text { health-care systems. }\end{array}$ \\
\hline 15 & 33 & 2016 & $\begin{array}{l}\text { South } \\
\text { Africa }\end{array}$ & $\begin{array}{l}\text { Regulation of } \\
\text { Traditional } \\
\text { Medicine }\end{array}$ & $\begin{array}{l}\text { Traditional } \\
\text { Medicine }\end{array}$ & $\begin{array}{l}\text { The decolonialisation of medicine } \\
\text { in South Africa through including } \\
\text { traditional medicine }\end{array}$ & Review & $\begin{array}{l}\text { Methods and implementation regarding institutionalisation of THPs remains a } \\
\text { mystery and this is regardless of stakeholders standing to gain from its } \\
\text { promotion. However, the promising phenomenon is that the fundamental } \\
\text { foundations have been identified and believed to be based on 'effective } \\
\text { communication, mutual respect and trust, reciprocal education and training, } \\
\text { two-way referral and scientific testing of traditional medicines. }\end{array}$ \\
\hline 16 & 44 & 2011 & $\begin{array}{l}\text { United } \\
\text { Kingdom }\end{array}$ & $\begin{array}{l}\text { The regulation of } \\
\text { herbal medicine }\end{array}$ & $\begin{array}{l}\text { Traditional } \\
\text { Herbal } \\
\text { Medicines }\end{array}$ & $\begin{array}{l}\text { The implementation of the } \\
\text { "Traditional Use Directive" (TUD) } \\
\text { which will regulate herbal } \\
\text { medicines in the EU. }\end{array}$ & $\begin{array}{l}\text { Review/ } \\
\text { Editorial }\end{array}$ & $\begin{array}{l}\text { It has been concluded that regulating of THPs is no easy task, but the concern } \\
\text { remains that if they were to be left unregulated then possibilities of them } \\
\text { causing more harm than good are rife. But the other fear is that if they are } \\
\text { obliged to practice according to evidence-based medicine principles than they } \\
\text { could be regulated into oblivion. }\end{array}$ \\
\hline
\end{tabular}




\begin{tabular}{|c|c|c|c|c|c|c|c|c|}
\hline Number & Authors & $\begin{array}{l}\text { Year of } \\
\text { publication }\end{array}$ & $\begin{array}{l}\text { Study } \\
\text { location }\end{array}$ & Interest type & $\begin{array}{l}\text { Study } \\
\text { population }\end{array}$ & Aims of publication & $\begin{array}{l}\text { Overview of } \\
\text { methods }\end{array}$ & Results \\
\hline 17 & 32 & 1994 & Europe & $\begin{array}{l}\text { Regulation } \\
\text { Complementary } \\
\text { Medicine }\end{array}$ & $\begin{array}{l}\text { Complementary } \\
\text { Medicine }\end{array}$ & $\begin{array}{l}\text { Unpacking Legal reforms in } \\
\text { progress in the Netherlands and } \\
\text { the United Kingdom on } \\
\text { Complementary Medicine }\end{array}$ & Review & $\begin{array}{l}\text { European institutions have been witnessed to influence the development of } \\
\text { traditional medicine but the challenge of trying to harmonize training and } \\
\text { regulation of THPs remains to be seen as a challenge for the future. }\end{array}$ \\
\hline 18 & 41. & 2007 & $\begin{array}{l}\text { South } \\
\text { Africa }\end{array}$ & $\begin{array}{l}\text { Legislation } \\
\text { regarding } \\
\text { Traditional and } \\
\text { Complementary } \\
\text { Medicine }\end{array}$ & $\begin{array}{l}\text { Traditional and } \\
\text { Complementary } \\
\text { Medicine }\end{array}$ & $\begin{array}{l}\text { Reviewing policies and regulation } \\
\text { regarding Traditional and } \\
\text { Complementary Medicine and } \\
\text { unpacking the increased numbers } \\
\text { in the practitioners of the latter. }\end{array}$ & Review & $\begin{array}{l}\text { Various authors argue that the reimbursement by medical schemes and } \\
\text { integration of traditional medicine into public and private facilities is far } \\
\text { behind with respect to legislative developments. }\end{array}$ \\
\hline 19 & 49 & 2003 & $\begin{array}{l}\text { Hong } \\
\text { Kong }\end{array}$ & $\begin{array}{l}\text { Policies and } \\
\text { regulation of } \\
\text { Traditional } \\
\text { Medicine }\end{array}$ & $\begin{array}{l}\text { Traditional } \\
\text { medicine }\end{array}$ & $\begin{array}{l}\text { An exploration into integrating } \\
\text { Traditional medicine with Modern } \\
\text { medicine and the policy } \\
\text { implications }\end{array}$ & $\begin{array}{l}\text { Qualitative/ } \\
\text { Review }\end{array}$ & $\begin{array}{l}\text { There are strong arguments that medical pluralism will be most balanced if } \\
\text { under measures that will be non-discriminating between various traditions } \\
\text { and should neither be full fused nor totally separated, but rather have strong } \\
\text { cross-sectional links between the various distinct traditions. }\end{array}$ \\
\hline 20 & 30 & 2018 & Canada & $\begin{array}{l}\text { Statutory } \\
\text { Regulation of } \\
\text { Traditional } \\
\text { Medicine } \\
\text { Practitioners and } \\
\text { Practices }\end{array}$ & $\begin{array}{l}\text { Traditional } \\
\text { Medicine } \\
\text { Practitioners } \\
\text { and Practices }\end{array}$ & $\begin{array}{l}\text { A review of Statutory Regulation } \\
\text { of Traditional Medicine } \\
\text { Practitioners and Practices and } \\
\text { the proposal of a need for distinct } \\
\text { policy making guidelines }\end{array}$ & Review & $\begin{array}{l}\text { Regulators of THPs are believed to be faced with epistemic, evidentiary } \\
\text { tensions and policy complexities surrounding the intersection of cultural and } \\
\text { clinical considerations. }\end{array}$ \\
\hline 21 & 53 & 2009 & Australia & $\begin{array}{l}\text { Regulatory } \\
\text { requirements of } \\
\text { naturopathy and } \\
\text { western herbal } \\
\text { medicine }\end{array}$ & $\begin{array}{l}\text { Naturopathy } \\
\text { and Herbal } \\
\text { Medicine }\end{array}$ & $\begin{array}{l}\text { The current state of usage and the } \\
\text { practice of naturopathy and } \\
\text { western herbal medicine, and to } \\
\text { ascertain whether statutory } \\
\text { regulation was warranted. }\end{array}$ & Review & $\begin{array}{l}\text { Protection and public health safety were issues that have been identified as } \\
\text { general failures of existing systems of self-regulation and this was found in } \\
\text { communities that have an increased use of traditional medicine therapies. } \\
\text { More concerning was the highly variable standards of training, countless } \\
\text { professional associations that were found to exist within these medicine } \\
\text { therapies. }\end{array}$ \\
\hline 22 & 46 & 1998 & $\begin{array}{l}\text { United } \\
\text { Kingdom }\end{array}$ & $\begin{array}{l}\text { Regulation of } \\
\text { Herbal } \\
\text { Practitioners }\end{array}$ & $\begin{array}{l}\text { Herbal remedies } \\
\text { and } \\
\text { Practitioners }\end{array}$ & $\begin{array}{l}\text { A review of risks of herbal } \\
\text { remedies and the evaluation of } \\
\text { their safety in the UK, as well as } \\
\text { the regulation of herbal } \\
\text { practitioners }\end{array}$ & Review & $\begin{array}{l}\text { The problem of non-disclosure of patients to their doctors continues to } \\
\text { hamper knowledge about the efficacy of traditional medicine, and this is } \\
\text { regardless of the supportive evidence coming from clinical trials. However, } \\
\text { many people believe that they derive real benefits from traditional remedies. }\end{array}$ \\
\hline 23 & 45 & 2010 & China & $\begin{array}{l}\text { Regulatory } \\
\text { headways of } \\
\text { Chinese Medicine }\end{array}$ & $\begin{array}{l}\text { Traditional } \\
\text { Chinese } \\
\text { Medicine }\end{array}$ & $\begin{array}{l}\text { This article summarizes studies on } \\
\text { TCM utilization, and regulatory } \\
\text { and educational development with } \\
\text { a focus on updating the TCM } \\
\text { clinical evidence from RCTs and } \\
\text { systematic reviews over the last } \\
\text { decade. }\end{array}$ & $\begin{array}{l}\text { Randomised } \\
\text { Control } \\
\text { Trials and } \\
\text { Reviews }\end{array}$ & $\begin{array}{l}\text { Published trials and systematic review have demonstrated significant efforts } \\
\text { to validate the quality, efficacy, and safety of traditional medicine. } \\
\text { Unfortunately, most of these trials have showed inconclusive data due to the } \\
\text { lack of quality and quantity of the trials to answer specific and answerable } \\
\text { clinical questions. }\end{array}$ \\
\hline 24 & 47 & 2014 & $\begin{array}{l}\text { South } \\
\text { Africa }\end{array}$ & $\begin{array}{l}\text { Regulation of } \\
\text { African } \\
\text { Traditional } \\
\text { Medicine }\end{array}$ & $\begin{array}{l}\text { African } \\
\text { Traditional } \\
\text { Medicine }\end{array}$ & $\begin{array}{l}\text { This review aims to raise } \\
\text { awareness of African traditional } \\
\text { medicine healthcare practice and } \\
\text { its implications in a perioperative } \\
\text { population. }\end{array}$ & Review & $\begin{array}{l}\text { Regardless of the widespread use of traditional medicine, there seems to be } \\
\text { compelling difficulties to conduct randomised control trials. This therefore has } \\
\text { an effect of depriving the research field of knowing its true extent and the } \\
\text { ability to extrapolate from traditional medicine use from the developed world. }\end{array}$ \\
\hline 25 & 52 & 2010 & South & Regulation and & African & Consideration of African & Review & Against compelling dominance of biomedical health care, South Africa is \\
\hline
\end{tabular}




\begin{tabular}{|c|l|l|l|l|l|l|l|l|}
\hline Number & Authors & $\begin{array}{l}\text { Year of } \\
\text { publication }\end{array}$ & $\begin{array}{l}\text { Study } \\
\text { location }\end{array}$ & Interest type & $\begin{array}{l}\text { Study } \\
\text { population }\end{array}$ & Aims of publication & $\begin{array}{l}\text { Overview of } \\
\text { methods }\end{array}$ & Results \\
\hline & & Africa & $\begin{array}{l}\text { Legalizing of } \\
\text { African } \\
\text { Tradititional } \\
\text { Medicine }\end{array}$ & $\begin{array}{l}\text { Traditional } \\
\text { Medicine }\end{array}$ & $\begin{array}{l}\text { Traditional Medicine (ATM) in } \\
\text { terms of the law and the national } \\
\text { health system of South Africa. }\end{array}$ & $\begin{array}{l}\text { believed to have made great strides in recognising, regulating, and integrating } \\
\text { traditional medicine into the national health system. }\end{array}$ \\
\hline
\end{tabular}




\section{FUNDING}

None

\section{AUTHORSHIP CONTRIBUTIONS}

All authors contributed to the design and writing of the manuscript.

\section{COMPETING INTERESTS}

The authors completed the Unified Competing Interest form at http://www.icmje.org/disclosure-of-interest/ (available upon request from the corresponding author) and declare no conflicts of interest.

\section{CORRESPONDENCE TO:}

Siyabonga Innocent Nzimande

(B. Com, BSocSc, MPP)

University of KwaZulu-Natal

School of Nursing and Public Health

Nzimande.siya259@gmail.com

Submitted: June 13, 2021 GMT, Accepted: July 12, 2021 GMT 


\section{REFERENCES}

1. Black J. Critical Reflection on Regulation. Australian Journal of Legal Philosophy. 2002;27.

2. WHO. The Promotion and Development of Traditional Medicine. World Health Organization; 1978:1-44.

3. Mokgobi MG. Views on Traditional Healing: Implications for Integration of Traditional Healing and Western Medicine in South Africa.; 2012.

4. Nattrass N. Who Consults Sangomas in Khayelitsha? An Exploratory Quantitative Analysis AU - Nattrass, Nicoli. Social Dynamics. 2005;31(2):161-182. doi:10.1080/02533950508628712

5. Zuma T, Wight D, Rochat T, Moshabela M. The role of traditional health practitioners in Rural KwaZuluNatal, South Africa: generic or mode specific? BMC Complement Altern Med. 2016;16(1):304. doi:10.1186/ $\underline{\text { s12906-016-1293-8 }}$

6. WHO. Traditional Medicine Strategy 2014-2023. In: Organization WH. Department of Essential Drugs and Medicines Policy; 2013:78.

7. Moshabela M, Bukenya D, Darong G, et al. Traditional healers, faith healers and medical practitioners: the contribution of medical pluralism to bottlenecks along the cascade of care for HIV/AIDS in Eastern and Southern Africa. Sex Transm Infect. 2017;93(Suppl 3). doi:10.1136/sextrans-2016-052974

8. WHO. Traditional Medicine Strategy 2014-2023. In: Organization WH. Department of Essential Drugs and Medicines Policy; 2013:78.

9. Alostad AH, Steinke DT, Schafheutle EI. International Comparison of Five Herbal Medicine Registration Systems to Inform Regulation Development: United Kingdom, Germany, United States of America, United Arab Emirates and Kingdom of Bahrain. Pharmaceutical medicine. 2018;32(1):39-49. doi:10.1007/s40290-018-0223-0

10. Madiba SE. Are biomedicine health practitioners ready to collaborate with traditional health practitioners in HIV and AIDS care in Tutume sub district of Botswana. African journal of traditional, complementary, and alternative medicines: AJTCAM. 2010;7(3):219-224.

11. Homsy J, King R, Balaba D, Kabatesi D. Traditional health practitioners are key to scaling up comprehensive care for HIV/AIDS in sub-Saharan Africa. Aids. 2004;18(12):1723-1725. doi:10.1097/01.a ids.0000131380.30479.16
12. Mngqundaniso N, Peltzer K. Traditional Healers and Nurses: A Qualitative Study on Their Role on Sexually Transmitted Infections Including HIV and AIDS in KwaZulu-Natal, South Africa. frican Journal of Traditional, Complementary, and Alternative Medicines. 2008;5(4):380-386.

13. Abdool Karim S, Tt ZP, Arendse R. Bridging the Gap: Potential for a health care partnership between African traditional healers and biomedical personnel in South Africa. 1994;84:S1-S6.

14. Leclerc-Madlala S, Green E, Hallin M. Traditional healers and the "Fast-Track" HIV response: is success possible without them? Afr J AIDS Res.

2016;15(2):185-193. doi:10.2989/16085906.2016.1204 $\underline{329}$

15. Fokunang C, Ndikum V, Tabi OY, et al. Traditional Medicine: Past, Present and Future Research and Development Prospects and Integration in the National Health System of Cameroon. Kamsu-Kom. 2011;8:284-295. doi:10.4314/ajtcam.v8i3.65276

16. Boon H. Regulation of complementary/alternative medicine: a Canadian perspective. Complementary therapies in medicine. 2002;10(1):14-19.

17. Hussain S, Malik F. Integration of complementary and traditional medicines in public health care systems: Challenges and methodology. 2013;7.

18. Gqaleni N, Hlongwane T, Khondo C, et al. BIOMEDICAL AND TRADITIONAL HEALING COLLABORATION ON HIV AND AIDS IN KWAZULUNATAL, SOUTH AFRICA. Published online 2011.

19. Awodele O, Amagon K. Traditional Medicine Policy and Regulation in Nigeria: An Index of Herbal Medicine Safety. Current Drug Safety. 2013;9. doi:10.2 174/1574886308666131126155434

20. Government Gazette. Traditional Health Practitioners Act, 2007. In: Health Do. Vol 511. Republic of South Africa; 2007:1-25.

21. Abrams A, Falkenberg T, Rautenbach C, et al. Legislative landscape for traditional health practitioners in Southern African development community countries: a scoping review. BMJ Open. 2020;10:1. doi:10.1136/bmiopen-2019-029958

22. Peckham S, Willmott M, Allen P, Goodwin N, Anderson S. Assessing the impact of the NHS Service Delivery and Organisation Research Programme. Evidence and Policy. Evidence and Policy. 2008;4(4):313. 
23. Arksey H, O’Malley L. Scoping studies: towards a methodological framework. International Journal of Social Research Methodology. 2005;8(1):19-32. doi:1 0.1080/1364557032000119616

24. Cooke A, Smith D, Booth A. Beyond PICO: the SPIDER tool for qualitative evidence synthesis. 2012;22:1435-1443. doi:10.1177/1049732312452938

25. Miller SA, Forrest JL. Enhancing your practice through evidence-based decision making: PICO, learning how to ask good questions. Journal of Evidence Based Dental Practice. 2001;1(2):136-141. do i:10.1016/S1532-3382(01)70024-3

26. Webster F, Krueger P, MacDonald H, et al. A scoping review of medical education research in family medicine. BMC Medical Education. 2015;15(1):79. doi:10.1186/s12909-015-0350-1

27. Dixon-Woods M, Cavers D, Agarwal S, et al. Conducting a critical interpretive synthesis of the literature on access to healthcare by vulnerable groups. BMC Medical Research Methodology. 2006;6:35-35. doi:10.1186/1471-2288-6-35

28. Armstrong R, Hall BJ, Doyle J, Waters E. 'Scoping the scope' of a cochrane review. Journal of Public Health. 2011;33(1):147-150. doi:10.1093/pubmed/fdr0 $\underline{15}$

29. Levac D, Colquhoun H, O’Brien KK. Scoping studies: advancing the methodology. Implementation Science: IS. 2010;5:69-69. doi:10.1186/1748-5908-5-6 9

30. Ijaz N, Boon H. Statutory Regulation of Traditional Medicine Practitioners and Practices: The Need for Distinct Policy Making Guidelines. Journal of alternative and complementary medicine (New York, NY). 2018;24(4):307-313. doi:10.1089/acm.2017.0346

31. Barimah K. Traditional healers in Ghana: So near to the people, yet so far away from basic health care system. 2016;6:9.1-9.6. doi:10.5667/tang.2016.0004

32. Fisher P, Ward A. Complementary medicine in Europe. BMJ (Clinical research ed). 1994;309(6947):107-111.

33. De Roubaix M. The decolonialisation of medicine in South Africa : threat or opportunity? : in practice healthcare delivery. South African Medical Journal. 2016;106(2):159-161. doi:10.7196/SAMI.2016.v106i $\underline{2.10371}$

34. Van Niekerk JP. Traditional healers formalised? South African Medical Journal. 2012;102(3):105-106.
35. Rautenbach C. Review on a new legislative framework for traditional healers in South Africa. Obiter. 2007;28(3):518-536.

36. Street RA, Street RA. Unpacking the new proposed regulations for South African traditional health practitioners. South African Medical Journal. 2016;106(4):325-326. doi:10.7196/SAMJ.2016.v106i $\underline{4.10623}$

37. Summerton J. The incorporation of African traditional health practitioners into the South African health care system. Acta Academica. 2006;38(1):143-169.

38. Mbatha N, Street RA, Ngcobo M, Gqaleni N. Sick certificates issued by South African traditional health practitioners: current legislation, challenges and the way forward: issues in medicine: forum. South African Medical Journal. 2012;102(3):129-131.

39. Dean E. Consultation on alternative therapy regulation launched. Nursing Standard (Royal College of Nursing (Great Britain)). 2009;23(49).

40. Caldis K, McLeod H, Smith P. The Fall of the Bamboo Curtain: A Review of Complementary Medicine in South Africa. 2001;1. doi:10.4314/saaj.v1i $\underline{1.24491}$

41. Gqaleni N, Moodley I, Kruger H, Ntuli A, McLeod $\mathrm{H}$. Traditional and complementary medicine: health care delivery. South African Health Review. 2007;2007(1):175-188.

42. Powlowski M. The Regulation of Traditional Practitioners: The Role of Law in Shaping Informal Constraints. North Carolina journal of international law and commercial regulation. 2006;32(2):195-258.

43. De Lange RW. Allopathic and traditional health practitioners: a reply to Nemutandani, Hendricks and Mulaudzi. African Journal of Primary Health Care and Family Medicine. 2017;9(1):1-4. doi:10.4102/phcfm.v9i $\underline{1.1284}$

44. Ernst E. The regulation of herbal medicine. International journal of clinical pharmacology and therapeutics. $2011 ; 49(4): 250-251$.

45. Xue CCL, Zhang AL, Greenwood KM, Lin V, Story DF. Traditional Chinese Medicine: An Update on Clinical Evidence. The Journal of Alternative and Complementary Medicine. 2010;16(3):301-312.

46. Shaw D. Risks or remedies? Safety aspects of herbal remedies in the UK. Journal of the Royal Society of Medicine. 1998;91(6):294-296. 
47. Nethathe GD, Russell SL. Traditional medicine use and the anaesthetist: review. Southern African Journal of Anaesthesia and Analgesia. 2014;20(6):221-225. do $\mathrm{i}: 10.1080 / 22201181.2014 .983711$

48. Berger M. Traditional medicine: a clear and present danger? South African Journal of Science. 2006;102(5-6):178-179.

49. Holliday I. Traditional Medicines in Modern Societies: An Exploration of Integrationist Options through East Asian Experience. The Journal of Medicine and Philosophy. 2003;28(3):373.

50. Mokgobi MG. Health care practitioners \&apos; opinions about traditional healing. African Journal for Physical Health Education, Recreation and Dance. 2014;20(Supplement 2):14-23.
51. Cho BH. The politics of herbal drugs in Korea. Social Science \& Medicine. 2000;51(4):505-509. doi:1 $\underline{0.1016 / S 0277-9536(99) 00492-X}$

52. Le Roux-Kemp A. A legal perspective on African traditional medicine in South Africa. Comparative and International Law Journal of Southern Africa. 2010;43(3):273-291.

53. Lin V, McCabe P, Bensoussan A, et al. The practice and regulatory requirements of naturopathy and western herbal medicine in Australia. Risk management and healthcare policy. 2009;2:21-33. do i:10.2147/RMHP.S4652 